\title{
Zirconium Zr 89 Cetuximab
}

National Cancer Institute

\section{Source}

National Cancer Institute. Zirconium Zr 89 Cetuximab. NCI Thesaurus. Code C78473.

A radioimmunoconjug ate comprised of the recombinant chimeric monoclonal antibody cetuximab labeled with the radioisotope zirconium $\mathrm{Zr} 89$ ( $\mathrm{Zr} \mathrm{89)}$ with radioisotopic activity and potential imaging use. The antibody moiety of zirconium $\mathrm{Zr} 89$ cetuximab binds to the extracellular domain of the epidermal growth factor receptor (EGFR). Upon binding, the radioisotope moiety may be detected using positron emission tomography (PET), allowing the imaging and quantification of EGFR-expressing tumor cells. EGFR is a tyrosine kinase that may be overexpressed on the cell surfaces of various tumor cell types. 